\title{
Mini Nurse Lite, Medical Tool Quiz and More: Smartphone Apps as Interactive English Medical Materials for Nursing Students
}

\author{
Fitri Handayani \\ Universitas Mahaputra Muhammad Yamin, Solok, Indonesia \\ fhandayani1786@gmail.com
}

\section{ARTICLE HISTORY \\ Received : 30 March 2021 \\ Revised : 2 April 2021 \\ Accepted : 13 June 2021}

\section{KEYWORDS}

English for Specific Purposes (ESP)

English as a Foreign Language (EFL)

Smartphone Applications

Nursing Students

English Medical

Learning Materials

Quantitative Research

\begin{abstract}
Gaining medical knowledge in English is challenging for nursing students due to the various challenging necessities such as possessing specialized vocabulary, diagnosing symptoms clearly, and writing health reports. To overcome these classical and practical language barriers, this study tries to establish the effects of using selected smartphone apps, i.e., Mini Nurse Lite, Disease Dictionary, Surgical \& Medical Instruments, and Medical Tool Quiz, to increase nursing students' ability in understanding English medical materials. This research employed a quasi-experimental pre-test and post-test design. The participants were 76 first-year nursing students of a selected university in Solok. The experimental treatment was teaching English medical materials through smartphone applications followed by discussion class, while the control group did not receive training in nursing with smartphone applications as only lecture-based education was performed. The results of the study showed that there was a higher mean score in levels of satisfaction by students in the experimental group (88.53) compared to the control group (82.27). It indicates that smartphone applications were effective for improving nursing students' ability in understanding English medical materials. The findings suggest optimal conditions for designing smartphone-based learning to be applied in a nursing class and contributed to the lack of studies on smartphone-based instruction in nursing within the context of overcoming English language barriers.
\end{abstract}

\section{Introduction}

As English is widely recognized as a lingua franca in various areas of the profession, English for Specific Purposes (ESP) demand is increasing rapidly, particularly in English as a Foreign Language (EFL) countries where English is used for educational purposes (Tsao, Wei \& Fang, 2008). In response to the strong demand for English in academic, vocational, and professional contexts, many colleges in Indonesia are now offering a variety of courses on a wide range of subjects for students to choose from, including English for nursing. English for nursing course is one of the sub-branches of English for Specific Purposes (ESP) targeted at non-English-speaking student nurses who use English both in the clinical setting and in nursing education (Mohamad \& Puteh, 2017; Nurakhir \& Palupi, 2018). This course becomes an important subject for the students to have a strong command of English and to use it for their future career.

For nursing students, having good English competence is not only just a subject to be achieved in their course, but also is beneficial for their career life in the future. They need English as a high level of assistance to achieve academic success and performance during clinical placements in their nursing programs (Boughton, Halliday \& Brown, 2010). It might become a valuable knowledge that makes them able to communicate in English with patients, doctors, and family in the context of health, and at the same time, they also know how to demonstrate using medical tools properly. Indeed, this knowledge automatically becomes urgent for them to support their performance in doing their job, such as attending an international conference and visiting foreign doctors or nurses for professional development (Marwa et al., 2021). Therefore, English plays a crucial role in nursing academic and future careers (Derin et al., 2020).

To get students having good English competence, The learning needs in English for Nursing course should cover all language skill suits to the students' needs and the situations in hospital or workplace. Saragih (2014), in his study, found that the topics most needed and wanted the course to cover were educating the patient, telephone skills, giving advice, giving instructions, checking to understand, explaining drug interactions, and administering medication. In line with this, Pongsapan (2015) also mentioned situations and topics in hospitals more frequently using English which was giving advice, explaining laboratory tests, monitoring the patient medication and treatments, managing patient admission, accident, and emergencies, pain, nutrition \& obesity. 
In fact, gaining knowledge of medical English is not easy to be achieved by nursing students. A lot of complexities and challenges are found during the teaching and learning process. A major challenge for students is learning specialized vocabulary because it is difficult to learn words, particularly in a medical context, because they are low-frequency words and are not frequently encountered (Xhaferi, 2010). As a result, it was difficult for students to grasp some new nursing terms that provided less response in the teaching and learning process (Rusanti \& Susandi, 2019). Besides that, the students seem to perceive difficulties in using English for clinical functions such as difficulties in figuring out the meaning of particular words about nursing stuff, pronouncing certain words correctly, diagnosing symptoms and health problems, and writing health problems' reports. These language barriers make them run the classroom activity very slow.

In addition, a previous study conducted by Rajasa (2018) found that nursing students' barriers to learning English in the classroom were classified into classical barriers and practical barriers. The classical barrier is related to grammar, structure, and tense. Meanwhile, the practical barrier came from the inadequacy of mastering four English skills; the lack of vocabulary for students to write stories, understand the text and read books, difficulty communicating with English, and problems with understanding the content in listening comprehension. Meanwhile, Crawford \& Candlin, (2013) declared other difficulties faced by nursing students in EFL classrooms which were problems with pronunciation, telephone communication, failure to comprehend colloquial expressions, and medical/nursing jargon. Further studies also have resulted that nursing students experienced obstacle in acquiring English term of nursing stuff and its definition, comprehending English nursing textbook, having good English communication on doing nursing activities, achieving English grammar and tense (Solak \& Bayar, 2015; Müller, 2011; Khan, 2011; Shakya \& Horsfall, 2000).

One way to cope with the students' challenges in language learning is by benefiting from technology. Current technological advances have made changes to the integration of materials in the language classroom more broadly (Vanderplank, 2010). The development of technology has a great effect on teaching language. It provides a lecturer on using tools to be appropriate and creative based on students' needs. Moreover, students also blend with the technology itself. They are aware of the use of technology in their daily life activities. It is beneficial to follow these trends -particularly well-known by young people- and to deliberate how it can be applied to teaching methods for language learning (Ahmed, 2015). For now, many technological devices are available to be used by teachers to enhance classroom learning. Personal digital assistants, tablet computers, smartphone, and laptops are examples of the device which can support the teaching and learning process.
The smartphone is one of the devices teachers and students are familiar with. It is a handheld telecommunication device that combines miniaturized hardware of a personal computer and a mobile phone with a relatively large touch screen. (Kulendran et al., 2014). From its feature, the smartphone has added functionality of a personal digital assistant (PDA), wireless Internet access, a compact digital camera, a global positioning system, and a high-resolution touch screen. This sophisticated tool is a common mobile device that students use on campuses and could be considered a possible tool for distributing learning materials to nursing students (Chuang, Chang, \& Wan, 2018). As a learning aid, the smartphone can make 'smart students smarter' by providing 10,275 unique applications labeled under ''Medical' and 'Healthcare and Fitness' categories (Gavali, Khismatrao, Gavali, \& Patil, 2017). Thus, the smartphone may be used for easy access to educational resources and instructions during the clinical, classroom, or clinical conferences (Phillippi \& Wyatt, 2011).

There have been numerous studies on the use of smartphone applications for language learning. The studies build on the various features of smartphone applications and highlight the wide potential of smartphones as a learning tool. Wong (2013), for example, developed a smartphone app to teach idioms to fifth graders in Singapore. In his study, he encouraged students to learn idioms using the software to take and organize pictures, create sentences and paragraphs, post objects on wiki sites, and select and combine existing pictures stored on a smartphone to generate new items. From the study, he concluded that the use of smartphones encourages authentic and effective language learning through careful applications and instructional designs. Andujar (2016) looked into WhatsApp application in language teaching. In his study, he found that WhatsApp offers the opportunity to develop the students' skills in second language writing and to enable their participation with its smartphone instant messaging. Naderi \& Akrami (2018) examined the effects of online reading comprehension instructions by Telegram (Messenger). The finding indicates that online instruction has become popular, and students choose smartphone as the best method for reading short texts.

Those studies, however, did not cover English for nursing. The studies did not look at how to utilize a smartphone to teach English medical materials. Generally, English medical materials are materials that enable students to learn and practice the language skills required to practice in nursing. The materials primarily concern experience and expertise in performing nurse duties at work, interacting in English with patients, physicians, and family members in the context of health, and demonstrating proper use of medical equipment.

Some studies have reported some English material necessary learned by nursing students. Fadliah (2019) in her study, reported that the students needed and wanted the 
course to cover such materials as to how to educate the patient, telephoning skills, communicating with patient and patient's family, and recognizing the workplace environment. Meanwhile, Wahyudi (2016) discovered that the nursing subjects most needed by students were around the hospital, nursing care, medical treatment, illnesses, and medication. Similarly, Putra, Padmadei, \& Budasi (2019) demonstrated that there were eight units of English for nursing students' materials that needed to be developed. These were Introduction, Giving Directions in Hospital, Health Problems, Types of Symptoms, Diagnosing Patient's Problems, Discussing Observation, Assessment, and Patient Assessment.

In short, in order to provide students with detailed information from English medical materials, it is important to employ suitable and innovative tools that are applicable to the students' experience and background. For that reason, a smartphone is one of the useful ways to be applied because of its familiar and easy use by the students. Thus, A study that focuses on specific smartphone applications will be a supplement to those studies in order to obtain an overall image of the best use of smartphone applications for learning English medical materials.

Given the importance and freshness of the issue and the lack of research on the role and place of smartphone in language learning for nursing students, this study aims to examine the effects of smartphone applications to enhance nursing students' understanding of medical English Materials at a selected university in Padang, Indonesia. The outcome of the study is expected to make a great contribution to encouraging other teachers or lecturers to use a smartphone application in teaching, to make it easier for students to learn, and to use it as a helpful input for other researchers to conduct further research on the subject of nursing.

\section{Literature Review}

A smartphone is a mobile device that is highly portable and accessible and can be used at any time and from any location (Kim \& Park, 2019). With this useful device, people can find and provide information, cultural activities, learning tools, economic activities, and social communication more easily and quickly. Smartphone applications, in particular, are thought to be appropriate for nursing education. Smartphone facilitates self-regulatory and active learning by motivating students and promoting collaboration and communication among students due to their high level of portability and accessibility. Thus, smartphone-assisted learning can explain medical guides to students in a flexible manner, and students can have more time to effectively familiarize themselves with the content of the materials (Waldmann \& Weckbecker, 2013).

A number of studies have sought to assess the effectiveness of some smartphone applications for nursing education. Mosa, Yoo, and Sheets (2012) conducted a survey of several smartphone-based software applications for healthcare professionals, medical or nursing students, and patients. They discovered 83 applications that could be used for specific purposes. For details, 57 applications were beneficial to healthcare professionals (disease diagnosis, drug reference, medical calculators, literature search, clinical communication, Hospital Information System (HIS) client applications, medical training, and general healthcare applications); 11 applications were beneficial to medical or nursing students focusing on medical education; and 15 applications were beneficial to patients (disease management, ENT-related, fall-related). From those all, the disease diagnosis, drug reference, and medical calculator applications were reported as most useful by healthcare professionals and medical or nursing students. According to the findings, the use of smartphones in healthcare is gaining more attention by the day. Medical applications for smartphones play an important role in assisting healthcare professionals, medical or nursing students, and patients in providing evidence-based care.

In addition, Kim \& Park (2019) also investigated on Effects of smartphone-Based Mobile Learning in Nursing Education. The results of this study revealed that smartphone-based mobile learning was effective in improving nursing students' attitudes toward learning and had a positive impact on the order of learning knowledge, skills, and confidence in learning. On the other side, Rachmawati (2020) investigated the nursing students' need for learning media for learning English. The findings revealed that those students required a learning tool or learning media that was adaptable so that they could access English content at any time and from any place. They need a learning media that is equitable, simple to use, and adaptable in order to communicate with English-speaking materials. In this case, a smartphone is a type of learning media that can assist them in always having access to English at any time and from any place.

Smartphones may be simply included in nursing curriculum. During the lesson, students can use their smartphones to update their medication knowledge, verify their clinical experience in terms of hours, and access reference books or e-books (Du, Liu, Liu, Yin, Xu, Zhang, \& Wang, 2013; Zhan, 2014). The previous studies concentrated on the effectiveness of using a smartphone for nursing education. They are, however, inadequate in providing a full picture of how students learn English medical materials more effectively by practical application. A study that shows the effectiveness of using medical smartphone applications to enhance English medical materials for nursing is thereby necessary.

\section{Method}

This research employed experimental research by using pre-test -post-test control group design. The main purpose of this research was to investigate the effect of a smartphone application to enhance nursing students' understanding of medical English. 
The participants were purposively chosen from the students registered in the First Semester of the Academic Year 2018/2019 in English for Nursing 1, a course in Nursing Education taught at the Politeknik Kesehatan Kementrian Kesehatan (Poltekes Kemenkes) Padang Program Studi DIII Keperawatan Solok, Sumatera Barat, Indonesia. The sample consisted of 76 nursing students (38 class A, 38 class B).

The instrumentation of this research was a reading test. The test was delivered in a multiple-choice form. The reading test contained materials about dimensions of symptoms, medical equipment, health problems, medical and nursing terminology. The total numbers of items were 40 items, of which ten items for each material.

To evaluate the quality of the test, the researcher measured the validity and reliability of the test. For validity, the researcher used content validity in which the item of the test constitutes a representative sample of the intended aspect. Meanwhile, measuring the reliability of the test used K - R. 21 formula that was proposed by Kuder \& Richardson (1937).

$$
r_{11}=\left(\frac{k}{k-1}\right)\left[1-\frac{M(k-M)}{k V_{t}}\right]
$$

Which:

$$
M=\frac{\sum x}{N} \quad V_{\mathrm{t}}=\frac{\sum x^{2}-\frac{\left[\tilde{L}_{0} x_{0}^{2}\right.}{N}}{N}
$$

In which:

$\mathrm{r}_{11} \quad=$ the reliability instrument

$\mathrm{k}=$ the total number of items

$\mathrm{M} \quad=$ the mean of students' scores

$V_{t} \quad=$ the total variances $\left(\mathrm{S}^{2}\right)$

$\sum \mathrm{x}=$ the sum of the students' scores

$\sum X^{2}=$ the sum square of the students' scores

$\mathrm{N}=$ the sum of the students

Table 1. Value Interpretation of $r_{11}$ (Arikunto, 2010)

\begin{tabular}{cc}
\hline Value of $\mathbf{r}_{11}$ & Interpretation \\
\hline $0,800-1,00$ & Very high \\
$0,600-0,790$ & High \\
$0,400-0,590$ & Enough \\
$0,200-0,390$ & Low \\
$0,00-0,190$ & Very Low \\
\hline
\end{tabular}

The reliability of the instrument of this research was 0,68 . It indicated that the reliability of the instruments of this research was high. The researcher considered some points in the selection of the applications before giving the treatment to the experimental class. First, the application should conform to the students' ability. The range of complexities offered in the apps is almost the same as the student's condition, so they may find the apps are really useful for them to help their learning process. Second, the applications must be developed by native speakers of English so that students can get authentic resources to learn medical English. Third, the content of the application must be sufficient with the students' topics and curriculum in their study. Fourth, the apps are available to be downloaded free in the students' mobile operating systems. Finally, the apps are crafted for small segments, engaging, exciting, and addictive. Based on these considerations, the researcher used Mini Nurse Lite, Disease Dictionary, Surgical \& Medical Instruments, and Medical Tool Quiz as the main applications during the research.

The treatments for the experimental class were done in four weeks. The students were provided with weekly themes, and after that, they were asked to participate and complete all weekly activities. Begin with the first week, the students were introduced to the apps for nursing English and were trained on how to obtain the apps. After that, they got practiced learning medical materials using the apps. The materials were closed to the nursing curriculum, and this research focus on four topics; medical and nursing terminology, medical equipment, dimensions of symptoms, and health problems. They received an in-class course for 150 minutes one week.

In the first meeting, the students began to use the Mini Nurse Lite app in learning about medical and nursing terminology. From this app, they got general information about medical terminology, medical abbreviations, medical suffixes, and prefixes. The researcher made lists of the medical terminology that they need to find out in the app. They were given time to learn in groups and discuss together with their friend about the lesson. They were also allowed to use other tools in their smartphone to help them during the discussion. After each group accomplishes their task, a classroom discussion was conducted to discuss the materials together. Finally, at the end of the course, the students were announced to get practice directly in answering exercises about medical and nursing terminology in the app.

Furthermore, the activities were continued from the second until the fourth meeting. In the second meeting, Surgical \& Medical Instruments app was used to teach medical equipment material. This app provides students information about the name and function of medical instruments included the pictures. They could know and identify the tools directly and know how to use them properly for their work. In checking students' understanding of this material, they were encouraged to do the task in the Medical Tool Quiz at the end of the meeting. Finally, in the third and fourth meetings, the students were encouraged to use the Disease Dictionary app in learning about dimensions of symptoms and health problems material. They were also given a quiz about diagnosing symptoms and health problems at the end of the meeting.

Every student's activity in the learning application was emphasized on the ability of reading comprehension. 
Students were equipped with learning videos, audio-related vocabulary, and associated website addresses for each activity that can be automatically linked to the internet. As a result, this would make it easier for students to comprehend the learning material. In analysing the data, the researcher calculated normality testing, homogeneity testing, and hypothesis testing as follows.

\subsection{Normality Testing}

This testing was used to determine the normality of the reading test's score between two groups of samples. The researcher measured the normality by using the Lilliefors formula proposed by Sudjana (2005).

$$
z_{i}=\frac{x_{1}-x}{S}
$$

In which:

Z1: Normality of test

$\mathrm{X} 1$ : Students' reading comprehension

$\mathrm{X}$ : Mean

S: Standard deviation

To calculate standard deviation, the researcher used a formula that was proposed by Sudjana $(2005$, p. 94) as follow:

$$
S=\sqrt{\frac{n \sum X_{i}^{2}-\left(\sum X_{i}^{2}\right)}{n(n-1)}}
$$

In which:

S: Standard deviation

$\mathrm{X}$ : Mean

$\sum \mathrm{Xi}^{2}$ : Sum square of students' score

To calculate the mean, the researcher used a formula that was proposed by Arikunto (2010).

$$
\bar{X}=\frac{\sum X}{n}
$$

In which:

$\mathrm{X}$ : The mean of students' score

$\sum x$ : Sum of students' score

$\mathrm{n}$ : The number of students

\subsection{Homogeneity Testing}

Homogeneity testing was done to determine whether the data of the two group samples have homogenous variance or not. The researcher used $\mathrm{F}$ ratio formula proposed by Sudjana (2005) as follow:

$$
F=\frac{S_{1}^{2}}{S_{2}^{2}}
$$

In which:

$s_{1}^{2}=$ Variances of the higher score

$s_{2}^{2}=$ Variances of the loweraacore

$\mathrm{F}=$ Ratio between two variables

The researcher compared the Fcalculate with $\mathrm{F}_{\text {table, with }}$ criteria if Fcalculate $\leq \mathrm{F}_{\text {table }}$, it means that distribution of the data has the same variances, nevertheless, when Fcalculate $\geq F_{\text {table. }}$. It means that the variances of the data distribution of the data were not the same.

\subsection{Hypothesis Testing}

To test the null hypothesis whether it was rejected or received, the researcher used the t-test formula that was proposed by Sudjana (2005).

$$
t=\frac{\bar{X}_{1}-\bar{X}_{2}}{S \sqrt{\frac{1}{n_{1}}+\frac{1}{n_{2}}}}
$$

In which:

$\mathrm{n}_{1} \quad=$ the number of students in experimental

group

$\mathrm{n}_{2}=$ the number of students in control group

$\bar{X}_{1} \quad=$ the mean scores of experimental group

$\bar{X}_{2} \quad=$ the mean scores of control group

$\mathrm{S}=$ Standard Deviation

To calculate standard deviation, the researcher used the formula below.

$$
S=\sqrt{\frac{\left(n_{1}-1\right) s_{1}^{2}+\left(n_{1}-1\right) s_{2}^{2}}{n_{1}+n_{2}-2}}
$$

In which:

$\mathrm{S}=$ Standard deviation

$n_{1}=$ The number of students in experimental group

$n_{1}=$ The number of students in control group

$s_{1}^{2}=$ Variances of the higher score

$s_{2}^{2}=$ Variances of the lower Score

The null hypothesis is received if $-\mathrm{t} 1-1 / 2 \alpha<\mathrm{t}<\mathrm{t} 1-1 / 2$ $\alpha$ otherwise, null hypothesis was rejected if $-\mathrm{t} 1-1 / 2 \alpha>\mathrm{t}$ $>\mathrm{t} 1-1 / 2 \alpha$.

\section{Results}

The data of this research was the students' scores in the reading tests; pre-test and post-test. Before doing the treatment, the pre-test had been administered to both classes to know the students' basic English abilities. This test was 
also used to see whether it has the same variances or homogenous. The analysis of students' pre-test scores at the experimental class and control class could be seen in Table 2.

Table 2. The Data of Students' Pre-test Scores

\begin{tabular}{lcccc}
\hline Class & $\mathbf{N}$ & $\overline{\mathbf{X}}$ & $\mathbf{X}_{\max }$ & $\mathbf{X}_{\min }$ \\
\hline Experiment & 38 & 84,13 & 96 & 60 \\
Control & 38 & 79,60 & 92 & 64 \\
\hline
\end{tabular}

Based on the data above, Nursing Students IA as an experimental class with 38 students got 84.13 mean scores. The highest score was 96, and the lowest score was 60 . Meanwhile, Nursing students IB as control class got 79.60 mean scores. In this case, the highest score was 92, and the lowest score was 64. The data above showed students' basic abilities in understanding English medical materials.

After giving treatment, a post-test was given to both classes. From the test, the mean score, standard deviations, and the variance of the data were analyzed. The analysis of students' post-test scores can be seen in Table 3 .
Table 3. The Data of Students' Post-test Scores

\begin{tabular}{lcccc}
\hline Class & $\mathbf{N}$ & $\overline{\mathbf{X}}$ & $\mathbf{X}_{\max }$ & $\mathbf{X}_{\min }$ \\
\hline Experiment & 38 & 88,53 & 96 & 64 \\
Control & 38 & 82,27 & 92 & 64 \\
\hline
\end{tabular}

Based on the data above, the mean score of the experimental class that was trained by using the smartphone application was greater than the means score of the control class that was not trained by using the smartphone application. To get a research conclusion, a t-test statistical analysis was used. The data analysis could be described in the following statistical analysis formulas.

\subsection{Normality Testing}

The first step in doing data analysis was to find the normality of the test. It was gotten from students' pre-test and post-test results from both the experimental and control class. The result of normality testing can be described in Table 4.

Table 4. The Result of Normality Testing of the Sample

\begin{tabular}{ccccccc}
\hline Class & Test & (n) & (a) & $\begin{array}{c}\text { Critical value of } \\
\text { accounting (lo) }\end{array}$ & $\begin{array}{c}\text { Critical } \\
\text { value of } \\
\text { table (lt) }\end{array}$ & Distribution \\
\hline \multirow{2}{*}{ Experimental } & Pre-test & \multirow{2}{*}{38} & 0,05 & 0,1454 & 0,161 & Normal \\
& Post-test & & & 0,1492 & 0,161 & Normal \\
\hline \multirow{2}{*}{ Control } & Pre- test & \multirow{2}{*}{38} & 0,05 & 0,1041 & 0,102 & 0,05 \\
\hline
\end{tabular}

In pre-test and post-test, the calculated normality coefficient from the experimental class were $\mathrm{L} 0=0,1454$ and 0,1492 respectively; the table normality coefficient was $\mathrm{Lt}=0,1610$, meaning that $\mathrm{L} 0<\mathrm{Lt}$. The data from the control class were $\mathrm{L} 0=0.1041$ and 0,1020 and $\mathrm{Lt}=0,1610$. It means that L0 < Lt. In sum, it showed that the data from both experimental and control classes were distributed normally, meaning that the data distribution was normal and there was no significant difference between the distribution for the pre-test and the post-test in both classes.

\subsection{Homogeneity Testing}

The next analysis done in this research was to find the variance of the data for both the experimental class and control class. It was analyzed through a homogeneity test. The description of the homogeneity test can be seen in the following table:

Table 5. The Result of Homogeneity Testing in Pre-test

\begin{tabular}{cccccccc}
\hline Class & $\mathbf{N}$ & $\overline{\mathbf{X}}$ & $\mathbf{S}$ & $\mathbf{S}_{\mathbf{2}}$ & $\mathbf{F}_{\mathbf{c}}$ & $\mathbf{F}_{\mathbf{t}}$ & Variance \\
\hline Experimental & 38 & 84,13 & 7,82 & 61,22 & \multirow{2}{*}{1,38} & \multirow{2}{*}{1,84} & Homogeneous \\
Control & 38 & 79,6 & 6,67 & 44,52 & & & \\
\hline
\end{tabular}

From the data above, it can be seen that Fcalculated $=$ 1,38 and $F_{\text {table }}=1,84$, it means that $F_{\text {calculate }} \leq F_{\text {table }}(1,38 \leq$ $1,84)$. In other words, the variance of both classes in the pre-test was homogeneous. It indicated that both of classes showed the same level and ability in the pre-test. 
Table 6. Result of Homogeneity Testing at Experimental Group

\begin{tabular}{cccccccc}
\hline Test & $\mathbf{N}$ & $\overline{\mathbf{X}}$ & $\mathbf{S}$ & $\mathbf{S}_{\mathbf{2}}$ & $\mathbf{F}_{\mathbf{c}}$ & $\mathbf{F}_{\mathbf{t}}$ & Variance \\
\hline Pre-test & \multirow{2}{*}{38} & 84,13 & 7,82 & 61,22 & \multirow{2}{*}{1,19} & \multirow{2}{*}{1,84} & Homogeneous \\
Post-test & & 88,53 & 7,18 & 51,57 & & & \\
\hline
\end{tabular}

From the data above, it could be seen $\mathrm{F}_{\text {calculate }}=1,19$, $\mathrm{F}_{\text {table }}=1,84 .(1,19 \leq 1,84)$, it means that $\mathrm{F}_{\text {calculated }} \leq$ Ftable $(1,19 \leq 1,84)$. In other words, the variance of both tests at the experimental class was homogeneous.
It shows that the student's learning outcomes between pretest and post-test in the experimental group had the same variant.

Table 7. Result of Homogeneity Testing at Control Group

\begin{tabular}{cccccccc}
\hline Test & $\mathbf{N}$ & $\overline{\mathbf{X}}$ & $\mathbf{S}$ & $\mathbf{S 2}$ & $\mathbf{F c}$ & $\mathbf{F t}$ & Variance \\
\hline Pre-test & \multirow{2}{*}{38} & 79,6 & 6,67 & 44,52 & \multirow{2}{*}{0,77} & \multirow{2}{*}{1,84} & Homogeneous \\
Post-test & & 82,27 & 7,62 & 58,13 & & & \\
\hline
\end{tabular}

From the data above, it could be seen $\mathrm{F}_{\text {calculate }}=0,77$, $\mathrm{F}_{\text {table }}=1,84 .(0,77 \leq 1,84)$, it means that $\mathrm{F}_{\text {calculated }} \leq \mathrm{F}_{\text {table }}$ $(0,77 \leq 1,84)$. In the other words, the variance of both tests at control class was homogeneous. It shows that the student's learning outcomes between pre-test and post-test in the control group had the same variant.

Table 8. Result of Homogeneity Testing in Post-Test

\begin{tabular}{cccccccc}
\hline Test & $\mathbf{N}$ & $\overline{\mathbf{X}}$ & $\mathbf{S}$ & $\mathbf{S}_{\mathbf{2}}$ & $\mathbf{F}_{\mathbf{c}}$ & $\mathbf{F}_{\mathbf{t}}$ & Variance \\
\hline Pre-test & \multirow{2}{*}{38} & 88,53 & 7,18 & 51,57 & \multirow{2}{*}{0.89} & \multirow{2}{*}{1,84} & Homogeneous \\
Post-test & & 82,27 & 7,62 & 58,13 & & & \\
\hline
\end{tabular}

From the data above, it can be seen that $\mathrm{F}_{\text {calculated }}=0,89$ and $F_{\text {table }}=1,84$, it means that $F_{\text {calculate }} \leq F_{\text {table }}(0,89 \leq$ $1,84)$. It could be concluded that the variance of both classes in the post-test was Homogeneous. From the data above, the researcher concluded that all of $F_{\text {calculate }} \leq F_{\text {table. }}$. It means that the variance of the experimental and control classes was homogenous. It signifies that the data have the same level in both classes and may be utilized in a t-test.

\section{Hypothesis Testing}

To know whether there was any differentiation of students' ability both in experimental and control classes, the researcher did a t-test statistical analysis. It could be seen on the following table:

Table 9. Result of t-test Experimental and Control Classes

\begin{tabular}{cccccccl}
\hline Test & $\mathbf{N}$ & $\overline{\mathbf{X}}$ & $\mathbf{S}_{\boldsymbol{2}}$ & (a) & $\mathbf{t}_{\text {cal }}$ & table & \multicolumn{1}{c}{ Reference } \\
\hline Experiment & \multirow{2}{*}{38} & 88,53 & 58,13 & \multirow{2}{*}{0.05} & \multirow{2}{*}{3,14} & \multirow{2}{*}{1,67} & Ho was received and \\
Control & & 82,27 & 51,57 & & & & Ha was rejected \\
\hline
\end{tabular}

The researcher got the data $\mathrm{T}_{\text {cal }}=3,14$ and $\mathrm{T}_{\text {table }}=1,67$.

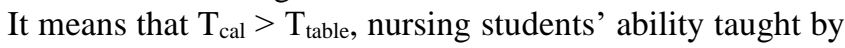
using smartphone application was better than students who were not taught by using a smartphone application. In other words, there was a positive effect on nursing students' ability to teach by using smartphone applications.

\section{Discussion}

After conducting the research, it was found that applying a smartphone application has a positive effect on nursing students' knowledge of English medical materials.
It was proved by the high average of students' post-test results. It can be seen from the data analysis that the mean score of the students who were taught by using a smartphone application was higher than students who were not taught by using a smartphone application. The result showed that the difference of the students' mean score was improved from 84,13 at pre-test to 88,53 at the post-test, with 4,40 improvement. It happens because smartphone application has several prominences that can give a positive influence on the students in learning English. 
Moreover, the researcher found that the students in the experimental class were so excited about the implementation of the medical smartphone application during the teaching process. It guided them to use all of their senses and could exchange their ideas about the information of the text in the group. The students became active when joining the games, they liked to see the video on the smartphone, and the students were easier answering the questions during discussion class. This research result supports the study performed by Chuang, Chang \& Wan (2018), which revealed that delivering learning materials through the smartphone to nursing students is suitable and can serve as a supplemental tool for learning nursing skills.

Furthermore, the results indicate that the use of smartphones and their applications have a positive impact on learning English, especially in the growth of the vocabulary of nursing students and their increased motivation to learn English. A range of educational applications, such as Mini Nurse Lite, Disease Dictionary, Surgical \& Medical Instruments, and Medical Tool Quiz, help students become more active, have more learning time, and have unlimited access to up-to-date knowledge and available material sources.

From those applications, the students got different experiences in learning English for different topics. Mini Nurse Lite application, for example, provides students with a basic description of learning medical terminology, medical abbreviations, medical suffixes, and prefixes. They got an appropriate tool for guiding them directly in learning medical technology. This app serves them a bunch of medical terminologies and abbreviations, which are easy to be learned and identified.

Then, the use of the Disease Dictionary application encourages students to become more independent and take responsibility for their own learning. The application provided students with comprehensive descriptions, symptoms, causes, and treatment details for medical conditions and diseases. They use this application as a clinical counselor for self-diagnosis, as well as to look up signs, illnesses, and treatments. As a result, they gained comprehensive knowledge of materials for understanding symptoms and health problems.

Also, the last two applications, Surgical \& Medical Instruments, and Medical Tool Quiz provide students with knowledge about the names and functions of medical instruments, as well as pictures of the instruments. They can directly recognize and describe the tools, as well as understand how to use them correctly for their work.

The current study results are similar with a few prior studies which examined the use of smartphone in nursing education. To explain, Phillippi \& Wyatt (2011) reported that the use of a smartphone engages and reinforces nursing students in learning by allowing them to quickly access educational materials, guidelines during clinical, class, or clinical conference, review instructional videos prior to performing skills, download applications, and reference materials. Similarly, George \& DeCristofaro (2016) emphasized that smartphone apps were highly received by students and enabled them to transfer learning from the classroom and laboratory to the community context. Therefore, smartphone applications were a useful and handy tool to stimulate active learning by offering quick access to educational materials in their clinical practice, as well as to engage students and reinforce learning at any time and from any location (Zhan, 2014).

In addition, it is unquestionable that smartphones, especially useful applications, play an important function as a means of communication and engagement between lecturers and students, as well as between students and their peers. During the research, lecturers and students were able to readily share information, assignments, and resources, as well as have online classes. This is especially good for students who are passive in class. They will be able to engage more directly without the embarrassment of having to deal with lecturers and other friends while in the face-toface class. This is in line with the findings of Chung, Subramaniam, \& Dass (2020), who discovered that university students who do not ask questions in face-to-face classes because of social shame will become active learners in using the application in the classroom. The applications then promote confidence, class involvement, and the willingness of students to utilize smartphones in education (Klimova \& Prazak, 2018). As a result, smartphone applications may easily improve students' enthusiasm to be engaged throughout the class.Overall, it is noteworthy that the use of a smartphone to learn medical English is an efficient and innovative way for nursing students to practice and improve their language skills. It is in line with the study proposed by O'Connor \& Andrews (2018), which reported that nursing students benefit from the use of smartphones, such as better access to educational materials, improvements in knowledge and confidence, and decreased levels of anxiety about learning in practice. Additionally, Chae \& Ha (2016) incorporated video recordings with a smartphone and formative feedback in the nursing education program. The results demonstrated that employing video recordings made with a smartphone and formative feedback was successful in enhancing understanding of basic fundamental nursing skills, clinical competency, self-efficacy, and learning motivation. Similarly, Choi et al. (2015) did research to verify communication skills training for nursing students using smartphone video clips. The findings found that the experimental group, which was given smartphone video clips, substantially improved in communicative competence and emotional intelligence when compared to the control group. Thus, the smartphone application had significant effects on the improvement of fundamental nursing practice competency, and learning satisfaction, and the apps are recommending educational planners take into account in future plans (Jeong, 2017; Musawi \& Baktash, 2021). 


\section{Conclusion}

This experimental study showed that there was a greater difference in nursing students' understanding of English medical materials when they are taught with smartphone applications specifically geared for their medical career. The study offers the novelty of testing out the effectiveness of four smartphone applications that can simultaneously enhance students' important medical knowledge and necessary specialised English vocabulary. Thus, the results of this study imply that suitable smartphone applications, such as Mini Nurse Lite, Disease Dictionary, Surgical \& Medical Instruments, Medical Tool Quiz and potentially others, have the potential to provide additional resources for students to enhance their language and knowledge, as well as their skills, in order to improve nursing students' achievement and success. Smartphones, therefore, are a highly valuable tool to facilitate the nursing students to learn English medical materials easily in the class because the students are provided a wide range of mobile ways to obtain medical information presented in English that can be accessed freely.

Although the findings of the study showed evidence that smartphones can be effective in facilitating language learning, some limitations were also established. First, the limited internet data and battery life owned by the student make them unable to optimally utilize the application during the lesson. Second, because of the small sample size in this study which was limited to 76 nursing students at a specific university in Indonesia, and the restricted number of applications used, the study results cannot be automatically generalized to other populations. For that reason, it is necessary to carry out another study with a larger number of nursing students in order to confirm - or falsify - the results presented in this study. Meanwhile, more studies will be needed in the future to examine strategies or learning activities in the context of ESP using the smartphone application. Finally, future studies with different research designs and focus on the use of such smartphone apps for teaching all four language skills would be required to confirm more reliable ad comprehensive results.

\section{References}

Ahmed, M. (2015). The effect of Twitter on developing writing skill in English as a foreign language. Arab World English Journal (AWEJ), 2, 134 -149.

Andujar, A. (2016). Benefits of mobile instant messaging to develop ESL writing. System, 62, 63-76.

Arikunto, S. (2010). Dasar-dasar Evaluasi Pendidikan. Jakarta: Bumi Aksara.

Boughton, M. A., Halliday, L. E., \& Brown, L. (2010). A tailored program of support for culturally and linguistically diverse (CALD) nursing students in a graduate entry Masters of Nursing course: A qualitative evaluation of outcomes. Nurse Education in Practice, 10(6), 355-360.

Chae, Y. J., \& Ha, Y. M. (2016). Effectiveness of education program for core fundamental nursing skills using recording video with smartphone and formative feedback. Journal of Digital Convergence, 14(6), 285-294.

Choi, Y., Song, E., \& Oh, E. (2015). Effects of teaching communication skills using a video clip on a smartphone on communication competence and emotional intelligence in nursing students. Archives of psychiatric nursing, 29(2), 90-95.

Chuang, Y. H., Lai, F. C., Chang, C. C., \& Wan, H. T. (2018). Effects of a skill demonstration video delivered by smartphone on facilitating nursing students' skill competencies and self-confidence: A randomized controlled trial study. Nurse education today, 66, 63-68.

Chung, E., Subramaniam, G., \& Dass, L. C. (2020). Online Learning Readiness among University Students in Malaysia amidst COVID-19. Asian Journal of University Education, 16(2), 46-58.

Crawford, T., \& Candlin, S. (2013). A literature review of the language needs of nursing students who have English as a second/other language and the effectiveness of English language support programmes. Nurse Education in Practice, 13(3), 181-185.

Derin, T., Nursafira, M. S., Yudar, R. S., Gowasa, N. S., \& Hamuddin, B. (2020). Persuasive Communication: What Do Existing Literature Tells Us About Persuasive Communication Among Students?. Utamax: Journal of Ultimate Research and Trends in Education, 2(1), 12-18.

Fadliah, U. (2019). Developing English Speaking Materials for Nursing Students. In 3rd International Conference on Current Issues in Education (ICCIE 2018) (pp. 503-508). Atlantis Press.

Gavali, M. Y., Khismatrao, D. S., Gavali, Y. V., \& Patil, K. B. (2017). Smartphone, the New Learning Aid amongst Medical Students. Journal of clinical and diagnostic research : JCDR, 11(5), JC05-JC08. https://doi.org/10.7860/JCDR/2017/20948.9826

George, T. P., \& DeCristofaro, C. (2016). Use of smartphones with undergraduate nursing students. Journal of Nursing Education, 55(7), 411415.

Jeong, H. (2017). Effects of nursing students' practices using smartphone videos on fundamental nursing skills, self-efficacy, and learning satisfaction in South Korea. Eurasia Journal of Mathematics, Science and Technology Education, 13(6), 23512365 . 
Khan, I. A. (2011). Challenges of Teaching/Learning English and Management. GLOBAL JOURNAL OF HUMAN SOCIAL SCIENCE, 11(8).

Kim, J. H., \& Park, H. (2019). Effects of smartphone-based mobile learning in nursing education: A systematic review and meta-analysis. Asian nursing research, 13(1), 20-29.

Klimova, B., \& Prazak, P. (2018, October). Evaluation of the effectiveness of the use of a mobile application on students' study achievements-a pilot study. In Conference on e-Business, e-Services and $e$ Society (pp. 37-44). Springer, Cham.

Kuder, G. F., \& Richardson, M. W. (1937). The theory of the estimation of test reliability. Psychometrika, 2(3), 151-160.

Kulendran, M., Lim, M., Laws, G., Chow, A., Nehme, J., Darzi, A., \& Purkayastha, S. (2014). Surgical Smartphone Applications Across Different Platforms: Their Evolution, Uses, and Users. Surgical Innovation, 21(4), 427440. https://doi.org/10.1177/1553350614525670

Marwa, M., Cahyono, B. Y., Latief, M. A., \& Prayogo, J. A. (2021). Intercultural Topics in the Indonesian English Language Teaching Classroom: Contextualizing Local and Neutral Cultures to Target and Global Cultures. Journal of Intercultural Communication, 21(1), 34-45.

Mohamad, A. F. N., \& Puteh, S. N. (2017). A CorpusBased Evaluation on Two Different English for Nursing Purposes (ENP) Course Books. Advances in Language and Literary Studies, 8(2), 196-201.

Mosa, A. S. M., Yoo, I., \& Sheets, L. (2012). A systematic review of healthcare applications for smartphones. BMC medical informatics and decision making, 12(1), 1-31.

Müller, A. (2011). Addressing the English language needs of international nursing students. Journal of Academic Language \& Learning, 5(2), A14-A22.

Musawi, S. Z., \& Baktash, J. A. (2021). Identification and Ranking of Cloud-Based Applications in E-Learning of Afghanistan: A Case of Public Universities. Elsya: Journal of English Language Studies, 3(2).

Naderi, N., \& Akrami, A. (2018). EFL Learners’ Reading Comprehension Development through MALL: Telegram Groups in Focus. International Journal of Instruction, 11(2), 339-350.

Nurakhir, A., Palupi, F. N. (2018). Exploring ESP Needs of Undergraduate Nursing Students in A University In Indonesia. Advances in Social Sciences Research Journal, 5(7).
O’Connor, S., \& Andrews, T. (2018). Smartphones and mobile applications (apps) in clinical nursing education: a student perspective. Nurse education today, 69, 172-178.

Phillippi, J. C., \& Wyatt, T. H. (2011). Smartphones in nursing education. CIN: Computers, Informatics, Nursing, 29(8), 449-454.

Pongsapan, N. P. (2015). Developing Instructional Materials for Nursing Students in Toraja South Sulawesi, Indonesia. Teaching English as a Foreign Language Overseas Journal, 1(1), 106-125.

Putra, I. G. A. P. (2019). Developing English Materials for Nursing Students of SMK Kesehatan Bali Medika Denpasar. Jurnal Pendidikan Bahasa Inggris Indonesia, 7(1).

Rajasa, G. (2018). Indonesian EFL Nursing Students' Learning Process: Obstacles \& Expectations. IJELTAL (Indonesian Journal of English Language Teaching and Applied Linguistics), 2(2), 133-149.

Rochmawati, D. (2020). The Nursing Students Need Of Learning Media For Learning English. JURNAL BASIS, 7(1), 33-46.

Rusanti, P., \& Susandi, N. K. A. (2019). Difficulties of Nursing Students in Learning English for Nurses (EFN) II at Institute of Technology and Health Bali. Singaraja-Bali| 5th-7th August, 2, 109.

Saragih, E. (2014). Designing ESP materials for nursing students based on needs analysis. International journal of Linguistics, 6(4), 59.

Shakya, A., \& Horsfall, J. M. (2000). ESL undergraduate nursing students in Australia: Some experiences. Nursing \& Health Sciences, 2(3), 163171.

Solak, E., \& Bayar, A. (2015). Current challenges in English language learning in Turkish EFL context. Participatory Educational Research,2(1), 106-115.

Sudjana, N. (2005). Metode statistika. Bandung: Tarsito.

Tsao, C. C. H., Wei, A. M. S., Fang, A. S. H. (2008). ESP for college students in Taiwan: A survey of student and faculty perceptions. In: 2008 International Symposium on ESP \& its application in Nursing \& Medical English Education. 2008. p. 245-262.

Vanderplank, R. (2010). Déjà vu? A decade of research on language laboratories, television and video in language learning. Language teaching, 43(1), 1-37.

Wahyudi, W. (2016). Developing English Learning Materials Based on Content-Based Approach For Nursing Students of Stikes Payung Negeri 
Pekanbaru. Proceedings of ISELT FBS Universitas Negeri Padang, 4(2), 417-425.

Waldmann, U. M., \& Weckbecker, K. (2013). Smartphone application of primary care guidelines used in education of medical students. GMS Zeitschrift für Medizinische Ausbildung, 30(1).

Wong, L. H. (2013). Analysis of Students' After-School Mobile-Assisted Artifact Creation Processes in a Seamless Language Learning Environment. Educational Technology \& Society, 16(2), 198-211.

Xhaferi, 2010 - Xhaferi, B. (2010). Teaching and learning ESP vocabulary. Revista de Lenguas para Fines Específicos, 16: 229-255.

Zhan, J. (2014). Evaluating and Designing Smartphone Applications for Nursing Education. In 2014 International Conference on Computer, Communications and Information Technology (CCIT 2014) (pp. 209-211). Atlantis Press. 